as to the desirability of such things as the application of objective criteria to the purchase of periodicals. At least one university library, Surrey, is now basing its periodicals purchasing policy on studies of $u^{2}{ }^{2}$, and the possible use of such aids as the Institute of Scientific Information's Journal Citation Reports is being actively examined in other libraries. Secondary journal citation is another approach being studied ${ }^{3}$.

It is also suggested that for a scientist to admit that he could not keep abreast of his own speciality would imply an incompetence. There is a confusion here between two separate and distinct areas of competence; competence as a scientist in a particular field of science, and competence as an information searcher. These two abilities are different, and the first does not necessarily imply the second. Many writers have commented on the difficulties encountered by scientists in using the literature ${ }^{4-8}$, and some scientists are prepared to admit their limitations in this field ${ }^{9}$. If past work is to be fully utilised, and duplication avoided, it is essential for all scientists to be aware of their own personal limitations, and to seek whatever assistance they require from professional information workers.

As long as there remain scientists who regard it as somehow infra dig to ask for advice or help on information problems, then some at least of these problems will be of their own making.

Yours faithfully,

D. M. SALter

The Library,

University of Exeter,

Prince of Wales Road,

Exeter EX广 $4 \mathrm{PT}$

${ }^{1}$ Bryan, H., Aust. Lib. J., 17, 389 (1968).

2 Annual Report, 1972-1979 (University of Surrey Library, 1973).

3 Windsor, D. A., Spec. Libr., 64, 446 (1973).

- Urquhart, D. J., in University Grants Committee, Report of the Committee on Libraries, 280 (HMSO, London, 1967).

5 Urquhart, D. J., Aslib Proc., 18, 351 (1966).

B Wood, D. N., and Barr, K. P., J. Doc., 22, 22 (1966).

${ }^{7}$ Bottle, R. T., in Progress in Library Science 1967 (edit. by Collison, R. L.), 109 (Butterworths, London, 1967).

8 Line, M. B., J. Labr., 1, 211 (1969).

${ }^{\circ}$ Schur, H., and Saunders, W. L., Education and Training for Scientific and Technological Library and Information Work, 37 (HMSO, Iondon, 1968).

\section{The individual and the information problem}

Sir,--Blaxter and Blaxter raise a number of interesting points in their recent paper (Nature, 246, 335; 1973). They are careful to emphasise that their results and conclusions obtain from the views and habits of full-time research scientists working in three biological research institutes, and that these may well differ from those of university lecturing staff, with educational commitments in addition to those of research. I should like to comment here on just one conclusion from the Aberdeen survey, however, and suggest that it may indeed be more generally applicable.

The Blaxters were able to estimate a figure for the total number of journals to be taken by a research institute's library to give $90 \%$ satisfaction to $90 \%$ of its users, a figure which was 25 times the number of 'fields' covered by the institute. The concept of a 'field' was defined by the publishing patterns of the individual scientist and the whole institute. For instance, for the institute cited, the number of non-overlapping fields was calculated to be five, so that the theoretically optimal number of journals to be taken by the library was only 125 .

In 1971 a survey was conducted in Edinburgh by interviewing a representative proportion of the staff of the medical school with the main purpose of obtaining an estimate of the journals that our central medical library ought to take to give reasonable satisfaction to its readership. Our survey was designed rather differently from the Aberdeen one and full details of its methodology and general results have been published ${ }^{1}$. From the results, we were able to obtain a total figure of approximately 580 unique primary and review journals covering all the major subject areas of biomedicine, except for social medicine, public health and dentistry, which were outside the scope of our survey. I must admit that we were pleasantly surprised and relieved that the figure was not higher.

For the library of a research institute, a holding of 580 carefully chosen journals is theoretically optimal for 23 non-overlapping fields with 25 journals per field, by the Blaxters' method of analysis. In the Edinburgh medical school survey, the 580 unique journals were in fact derived almost entirely from 47 subject areas as defined by the Index Medicus List of Journals. This corresponds to an average of 12 to 13 unique journals per subject area. Many individuals in our survey had an interest in the journals of more than one subject area, and between the various medical school departments there was evidence for considerable overlap of interest. It would therefore seem not unreasonable if a 'field' in the Blaxters' sense approximates roughly in size to two average subject areas in the Index Medicus sense.

Approximate techniques inevitably have to be used to estimate the optimal journal holding for a library serving a readership of any complexity. The important point is that, though based on different methodologies, both the Aberdeen and Edinburgh surveys produced the same conclusion: in spite of the information explosion, the optimal journal holding of a research institute or medical school library appears not to be so enormous after all, given, of course, adequate back-up facilities by a national loan service. In fairness to Edinburgh's medical school and library staff, I should add that financial restrictions have prevented our central medical library from as yet achieving the estimated optimal number of journals.

\section{Yours faithfully,}

Elizareth D. Whittle

Medical Information,

Faculty of Medicine,

Edinburgh University, Edinburgh

${ }^{1}$ Whittle, E. D., Br. J. med. Educ., 6, 306, (1972).

\section{Cognitive Subjective}

Gregory $^{1}$ should have acknowledged sources in references to his experiments and discussion of what he calls "cognitive contours" or, as others would have it, "subjective contours". ("Subjective contours" represents a neutral description, whereas "cognitive contours" suggests the role of an intellectual process.) He acknowledges Kanizsa as the source for his Fig. 1, but does not do so for his Fig. $2 c$, a figure also to be found in Kanizsa (Fig. 13) ${ }^{2}$. Gregory reports, in regard to one of his experiments, that the subjective contours of the Kanizsa figure can be obtained stereoscopically by proper presentation of parts to each eye. I had already reported the positive results of this experiment with a slightly modified Kanizsa figure, also showing diagrammatically the selection of parts for presentation in a stereoscope (page 296, page $405 n$. 14; ref. 3 ). In another experiment, he points out that the sides of the subjective triangle appear curved when the edges of the sectors are not collinear, an effect which he describes as "new". I had, however, also pointed this out: "The Kanizsa diagram itself can be modified so that the subjective contours are curved. The alignment of the edges of two sectors constitute a condition for straightness of subjective contours.. When the sectors are redrawn so that the edges are not aligned, a triangular shape with curved contours is seen" (page 404; ref. 3). Furthermore, I had noted the presence of subjective contours in the afterimage of an incomplete figure (page 406 n. 22; ref. 3), as had also Gregory. Nicholas Pastore

Department of Psychology,

Queens College of the

City University of New York,

Flushing, New York 11367 
Received October 27, 1972.

1 Gregory, R. L., Nature, 238, 51 (1972).

2 Kanizsa, G., Rivista di Psicologia, 49, 7 (1955).

${ }^{3}$ Pastore, N., Selective History of Theories of Visual Perception: 1650-1950 (Oxford University Press, New York, 1971)

Nature regrets delay in publishing this manuscript. A part of this delay can be attributed to the transition from one Editor to another.

\section{Announcements}

\section{Appointments}

A. L. Armitage, Vice Chancellor of the University of Manchester, has been elected Chairman of the Committee of Vice Chancellors of the United Kingdom.

The following have been elected Fellows of the Royal Society: W. F. Bodmer; W. R. Boon; K. Burton; H. J. F. Cairns; R. Y. Calne; D R. Curtis; J. F. Davidson; J. D. Dunitz; P. V. Edman; J. D. Eshelby; J. Halpern; S. W. Hawking; V. Heine; R. A. Hinde; A. E. Litherland; J. E. Lovelock; D. H. Matthews; R. E. F. Matthews; P. D. Mitchell; S. V. Perry; N. J. Petch; J. R. Philip; J. C. Polkinghorne; C. W. Rees; J. Rishbeth; R. V. Short; J. T. Stuart; R. H. S. Thompson; R. J. Vane; F. J. Vine; S. E. Wonds; and P. H. J. Young.

D. H. Wiffen has been appointed Dean of the Faculty of Science of the University of Newcastle upon Tyne.

Sir Eric Roll has been elected as Chancellor of the University of Southampton.

\section{Awards}

The Royal Geographical Society's Medals and Awards have been given to the following: C. Bonnington (Founder's Medal); G. de Q. Robin (Patron's Medal); C. A. Fisher (Victoria Medal); H. H. Lamb (Murchison Award) ; Captain D. W. Haslam (Back Award); M. A. J. Williams (Cuthbert Peek Award) ; A. R. H. Baker (Gill Memorial) ; Colonel J. M. Adam and I. Douglas-Hamilton (Ness Awards); and D. Bartlett and J. Bartlett (Cherry Kearton Medal and Award).

The Council of the Royal Society of Victoria has awarded Research Medals for 1973 to D. Metcalf and J. H. Willis.

W. T. Elwell of Imperial Metal Industries Ltd has been awarded the Gold Medal of the Society for Analytical Chemistry.

\section{Misscellaneous}

The International Health Foundation (1 place du Port, 1204, Geneva) has an- nounced that the theme chosen for its award scheme this year is Oral Contraception-a 1974 critical assessment. Applications are invited by the Council of the Royal Society (6 Carlton House Terrace, London SW1Y 5AG) for two Royal Society J. Sainsbury Research Fellowships.

\section{Erratum}

In the obituary of C. A. Coulson ( $\mathrm{Na}$ ture, 248, 367 (1974), who died on January 7,1974 , it was stated that he entered Trinity College, Cambridge from his local Grammar School. In fact he was educated at Cliften College, Bristol.

\section{Reports and Publications}

not included in the Monthly Books Supplement

\section{Great Britain and Ireland}

The Mental Health Trust and Research Fund. Annual Report and Accounts, 1973. Pp. 28. (London: The Mental Health Trust and Research Fund, 8 Wimpole Street, W1, 1973.)
UKAEA-Research Group. AERE-R 7540: Radioactive Fallout in Air and Rain-Results to the middle of 1973. By R. S. Cambray, Miss E. M. R. Fisher, A. Parker and D. H. Peirson, Pp. iii-38. (Harwell, Berkshire: Environmental and Medical Sciences Division, Atomic Energy Research Establishment. Available from HMSO.)
$£ 1$ net. imited. International Computers (Holdings), Limited.
Annual Report and Accounts, 1973. Pp. 24. Annual Report and Accounts, 1973. Pp. 24. (London: International Computers (Holdings)
Ltd., 1973.) Provisional Geochemical Atlas of Northern Ire-
and. ('Technical Communication No. 60) Pp. 30 . Imperial College of Science and Technology, 1973.) Г2012

Roraima: Report of the 1971 British Expedition to Mount Roraima in Guyana, South America Bdrian Warren, Whiteoaks, Harebell Hill, 1973.) [2812

\section{Other Countries}

Deutscher Wetterdienst. Duetsches Meteorologisches Jahrbuch, Bundesrepublik, 1970. Pp. xxxvi +242. (Offenbach a.M.: Deutscher Wetterdiesnt,

Forschungsberichte des Landes Nordrhein-West falen. Nr. 2313: Nachweis und Reizbedingungen Olfaktorisch und Rhinosensibel Evozierter Hirn rindensummenpotentiale Sowie Konzept einer Klnischen Computer-Olfaktometrie. Von Dr. Claus Herberhold. Pp. 126. (Opladen: Westdeutscher
Verlag, 1973.) 27.50 DM. International Union for Conservation of Nature and Natural Resources. IUCS Publications, New Series, No. 26: Planning for Man and Nature in National Parks-Reconciling Perpetuation and Use. By Richard R. Forster. Pp. 84. (Morges, tion of Nature and Natural Resources, 1973.)

Canada: Department of Energy, Mines and Resources. Geological Survey of Canada. Paper 73-25: Electromagnetic Fields of Oscilating Magnetic Dipoles Placed Over a Multilayer Conduct ing Earth, By A. K. Sinha and L. S. Collett, Pp. 48. \$2. Paper 73-28: An Ionization Chamber for Continuous Monitoring of Atmospheric Radnn.. Radon-222 Levels in Ottawa and Gatineau Hills, Canada. By Willy Dyck. Pp. vi+11. \$2. Geological Map 1342A: Kasheshibaw Lake, (East
Half), Newfoundland-Quebec. (Ottawa: Information Canada, 1973.)
mation Cand (Ottawa: InforEuropean Organization for Nuclear Research CERN. CERN 73.10: The Theory of Ionization Growth in Gases Under Pulsed and Static Fields. By A. J. Davies and C. J. Evans. Pp. $x+111$ Geneva: CERN, 1973.)

Bulletin of the American Museum of Natural History, Vol. 152, Article 4: A Revision of the Moth Genera Nepterotaea and Chesiadodes (Le-
pidoptera, Geometridae). By Frederick H. Rindge. pidoptera, Geometridae). By Frederick H. Rindge.
Institut National de la Santé et de la Recherche Médicale. La Cyroconservation des Cellcles Nor. males et Néoplasiques/ The Cyropreseravtion of Normal and Neoplastic Cells. (Proceedings of the 30, 1973.) Pp. 215. (Paris-Cedex: Institut National de la Santé et de la Recherche Médicale.
[1911

United States Department of the Interior: GeUnited States Department of the Interior: Ge-
ological Survey. Water-Supply Paper 2095: Quality of Surface Waters of the United States, 1968. Wart 6: Missouri River Basin. Pp. xi $394 . \$ 2.35$. Water-Supply Paper 2110: Surface Water Supply of the United States, 1966-70. Part 3: Ohio River Basin. Vol. 4: Ohio River Basin Below
Wabash River. Pp. ix +801 . $\$ 3.70$. Water-Supply Paper 2115: Surface Water Supply of the United Ptates 1966-70. Part 5: Hudson Bay and Upper Mississippi River Basins. Vol. 3: Upper Mississippi River Basin Below Kenkuk, Iowa. Pp. viii+607. \$3.20. Water-Supply Paper 2125: Surface Water Supply of the United States, 1966070. Part 9: Colorado River Basin. Vol. 2: Colorado River Basin From Green River to Compact Point. Pp. viii +634 . $\$ 32.00$ (Washington, DC: Government Printing Office, 1973.) [1911 Reports of the Australian Acarlemy of Science No. 16: Symposium on Biological Memory. of Science, 1973.) [2011 United States Denartment of the Interior: Ge ological Survey. Professional Paper 807: Geochemical Anomalies of a Claypit Area, Callaway ance in Beef Cattle. By Richard J. Ebens, James A. Erdman, G. L. Feder, Arthur A. Case and Liloyd A. Selby. Pp. iiit24. (Washington, DC Government Printing Office, 1973.) 65 cents.

Australian Academy of Science. Science and Industry Forum. Report No. 6: Industry and the Environment. Pp. 60. (Canberra, ACT Australian Academy of Science, 1973.) [2011 Statistical Office of the European Communitics. Basic Statistics of the Community: Comnarison
with some European Countries, Canada, the United with some European Countries, Canada, the United States of America, Japan and the Union of $\mathrm{So}^{-}$
view Socialist Republics. Twelfth edition. $\mathrm{Pp}$. 218. (Luxembourg: Statistical Office of the Furo. 218. (Luxembourg: Statistical Office of the Furo-
pean Communities, P.O. Box 1907,1973.) [211] International Atomic Energy Agency, Vienna. Bibliographical Series No. 41: Isotope Technique in Hydrology, Vol. II (1966-1971). Pp. 223. 190 schillings; $\Varangle 30 ; \$ 9$. Computer Models and $A p$ plication of the Sterile-Male Technique. (Proceedings of a Panel organized by the Joint $\mathrm{FAO}$ IAEA Division of Atomic Energy in Food and Agriculture, held in Vienna, 13-17 December 1971 Panel Proceedings Series.) Pp. 192 . 168 schill ings; $\begin{aligned} & £ 3.30 ; \\ & \text { HMSO, 1973.) }\end{aligned} 8$. (Vienna: IAEA; Yondon
[2111 Australian Journal of Zoology. Sunplement No. 22: The Sphaeroceridae ( $=$ Borroridae or CypSelidae; Diptera Cyclorrhapha) of the Australian Region. By O. W. Richards. Pp. 297-401. (East Melbourne. Victoria: Editorial and Publications Canada. Ministry of State-Science and Tech. nology. A Research Study on Science Communi. nology. A Research Study on Science Communi. Impact. Vol. 1: Interim Report.) $\mathrm{PD}$. 50. (Ottawa: Information Canada, 1973.)

Geophysics Research Board, National Geophysical Research Institute, Hyderabad. Progress in Geophysics: Report on the Geophysical Activities in the Republic of India, Issue Number $6 \&$ 7 January-December, 1970 and 1971. Pp. vi +240. (Hyderabad: Geonhysics Research Brard, National Geophysical Research Institute, 1973.) [221] Australia: Commonwealth Scientific and Industrial Research Organization. Twenty-fifth Annual Victoria: CSIRO, P.O. Box 89, 1973.) [2311] Deutsche Forschungsgemeinschaft. Denkschrift Epilepsie. Verfasst von Dieter Janz, in Zusammenarbeit mit $H$. Coper, O. Creutzfeldt, H. Doose, R. Dreyer, G. Latsch, H. Penin und G. Veith. Pp. 141. (Bonn

Australian Journal of Zoology, Supplement No 23: The Tanytarsini (Diptera. Chironomint Australia By B. Glover. Pp 403-478. (Eas Melbourne: Editorial and Publications Service, CSIRO, 372 Albert Street, 1973.) 「231 dustrial Research Organization, Division of Fish eries and Oceanography Technical Paper No 35 : Hydrology of the Gulf of Carpentaria, 1970/1971. By B. S. Newell. Pp. 29. (Melbourne: CSIRO,
1973.) Australia: Commonwealth Scientific and In dustrial Research Organization. Annual Repor of the Division of Animal Health, 1972. Pp. 123 (Melhourne: CSIRO, 1973.)
Review of the Fisheries Research Board of Review of the Fisheries Research Board of
Canada, 1971/1972. Pp. 230. (Ottawa: Informa. tion Canada, 1973.) 11712 Office de la Recherche Scientifique et Technique Outre-Mer. Memoire ORSTOM, No. 68: Les Savanes du Sud-Ouest de Madagascar. Par $P$ Morat. Pp. 235. 92 francs. Travaux et Docu-
ments de loRSToM No. 25: Etude d'Une Plante ments de l'ORSTOM No. 25: Etude d'Une Plante
Médicinale Malgache, Buxus madagascarica Baill Médicinale Malgache, Buxus madagascarica Baill,
et ses Variétes. Par R. S. Razafindrambao. 25 et ses Variétes. Par R. S. Razafindrambao. francs. (Paris et Bondy: Office de la Recherche
Scientifique et Technique Outre-Mer, 1973.) 